\title{
Preferential Hemolysis of Immature Erythrocytes in Experimental Iron Deficiency Anemia: Source of Erythropoietic Bilirubin Formation
}

\author{
StePhen H. Robinson and Ellen KoepPel \\ From the Department of Medicine, Beth Israel Hospital and Harvard Medical \\ School, Boston, Massachusetts 02215
}

\begin{abstract}
A в S T R A C T Bilirubin ${ }^{14} \mathrm{C}$ production was measured in rats transfused with labeled erythrocytes from animals with iron deficiency anemia, a condition associated with ineffective erythropoiesis. With labeled reticulocytes harvested 1 day after the administration of glycine- $2 \cdot{ }^{14} \mathrm{C}$, conversion of hemoglobin $-{ }^{14} \mathrm{C}$ to bilirubin averaged $47.3 \%$ over the 3 days of observation; the corresponding value for reticulocytes from normal rats was only $1.7 \%$. Findings were not altered by splenectomy. Bilirubin $-{ }^{14} \mathrm{C}$ production fell to $35.8 \%$ with iron-deficient cells harvested 3 days after glycine- ${ }^{14} \mathrm{C}$ administration, and declined further to a plateau averaging $25 \%$ with cells labeled $5,7,10$, or 15 days earlier. The latter values still far exceed those for mature erythrocytes from normal animals.

The findings indicate that experimental iron deficiency anemia is associated with hemolysis of red cells of various ages, but with preferential destruction of the youngest cells. Degradation of hemoglobin from reticulocytes is sufficient to account for a major fraction of the increase in erythropoietic bilirubin production found in this disorder, as has also been shown for physiologically regulated erythroid hyperplasia. However, the defect is quantitatively much more striking in experimental iron deficiency, and this and perhaps a similar defect in bone marrow cells appear to explain the decrease in net hemoglobin production that is characteristic of pathologic ineffective erythropoiesis.
\end{abstract}

\section{INTRODUCTION}

As adduced from isotopic studies, approximately $15 \%$ of normal bile pigment production originates from

Parts of this work were presented at the Annual Meetings of the American Society for Clinical Investigation, Atlantic City, N. J., May 1969 (1), and the American Society of Hematology, San Juan, P. R., December 1970 (2).

Received for publication 20 January 1971 and in revised form 14 April 1971. sources other than the hemoglobin of senescent erythrocytes (3-5). In rats under normal conditions, most of this "early-labeled" bilirubin fraction is derived from extra-erythroid sources, primarily in the liver (5-10). In addition, an erythropoietic component is contained within the later phases of the early-labeled fraction (5, $10)$. This component is small in rats under physiological conditions (5), but appears to have a larger role in species such as man and the dog $(10,11)$.

Enlargement of the erythropoietic phase of bile pigment production is found with both accelerated red cell formation in normal animals and man $(5,10-13)$ and disordered erythropoiesis in subjects with certain hematologic diseases (14-17). It has been generally assumed that this is due to ineffective erythropoiesis (18), i.e., hemolysis of immature erythroid cells. However, this concept has been difficult to substantiate directly. Moreover, it has not been ascertained whether the erythropoietic bilirubin fraction has similar origins in subjects with physiologically regulated as compared with pathologically disordered red cell production (19).

Recent studies in this laboratory have shown that degradation of hemoglobin from immature erythroid cells in the peripheral blood, i.e. reticulocytes, ${ }^{1}$ accounts for a major portion of the enlarged erythropoietic fraction in rats undergoing a physiologic response to blood loss (21). A rise in erythropoietic bilirubin production has also been found in rats with iron deficiency anemia (22); however, this is associated with a decrease rather than an increase in the net production of red cell hemoglobin heme, a pattern characteristic of pathologic ineffective erythropoiesis $(5,14-17)$. Investiga-

\footnotetext{
${ }^{1}$ For convenience, the term "reticulocyte" is used for circulating red cells that are labeled $24 \mathrm{hr}$ after the administration of glycine-2-14 $\mathrm{C}$. Only immature erythroid cells have the capacity to synthesize hemoglobin heme from this physiologic precursor (20). However, some such young cells might not actually stain as reticulocytes.
} 
TABLE I

Conversion of Reticulocyte Hemoglobin Heme- ${ }^{-14} \mathrm{C}$ to Bilirubin ${ }^{14} \mathrm{C}$ under Different Conditions

\begin{tabular}{|c|c|c|c|}
\hline Cell type & Condition & $\begin{array}{l}\text { No. } \\
\text { of } \\
\text { recip- } \\
\text { ients }\end{array}$ & $\begin{array}{l}72 \mathrm{hr} \text { con- } \\
\text { version of } \mathrm{Hb} \\
\text { heme-14C to } \\
\text { bilirubin-14 } \mathrm{C}^{*}\end{array}$ \\
\hline \multirow[t]{3}{*}{$\begin{array}{l}\text { Iron-deficient } \\
\text { reticulocytes }\end{array}$} & $\begin{array}{l}\text { Splenectomy } \\
\quad \text { (donors/recipients) } \ddagger\end{array}$ & & $\%$ \\
\hline & $\begin{array}{l}\text { Sham/sham } \\
\text { Sham/splenx } \\
\text { Splenx/sham }\end{array}$ & $\begin{array}{l}4 \\
4 \\
5\end{array}$ & $\begin{array}{l}46.6 \pm 7.6 \\
49.8 \pm 6.9 \\
45.9 \pm 8.9\end{array}$ \\
\hline & Combined & 13 & $47.3 \pm 8.3$ \\
\hline $\begin{array}{l}\text { Normal } \\
\text { reticulocytes }\end{array}$ & $\begin{array}{l}\text { Cells from } \\
\text { normal rats }\end{array}$ & 6 & $1.7 \pm 0.5$ \\
\hline $\begin{array}{l}\text { Normal } \\
\text { reticulocytes }\end{array}$ & $\begin{array}{l}\text { Cells from iron- } \\
\text { treated controls }\end{array}$ & 2 & $1.0,2.7$ \\
\hline $\begin{array}{l}\text { Normal } \\
\text { reticulocytes }\end{array}$ & $\begin{array}{l}\text { Incubated with iron- } \\
\text { deficient plasma }\end{array}$ & 1 & 2.5 \\
\hline $\begin{array}{l}\text { Normal } \\
\text { reticulocytes }\end{array}$ & $\begin{array}{l}\text { Iron-deficient } \\
\text { recipients }\end{array}$ & 2 & $4.1,4.9$ \\
\hline
\end{tabular}

Values are means $\pm S D(26)$.

* Transfusions contained 1.46 to $4.51 \times 10^{5} \mathrm{dpm}$ in hemoglobin heme-14 $\mathrm{C}$.

‡ Sham donors include both nonoperated and sham-operated rats because of lack of difference between the two.

\& Previously iron-deficient rats treated with iron dextran (see Methods).

tions were therefore undertaken to evaluate the role of reticulocyte hemolysis in this experimental model.

\section{METHODS}

Methods were generally similar to those used in previous experiments $(21,22)$. Male rats from a Bartonella-free cesarian-derived strain $^{2}$ were rendered iron-deficient from the time of weaning by special diet (22) and were studied at 2-3 months of age when they weighed $100-240 \mathrm{~g}$. Several control animals were kept on the same regimen, but were restored to hematologic normalcy with intramuscular injections of iron-dextran (22). Additional control values were derived from previous data (21) for normal rats on a standard laboratory diet after it had been ascertained that experimental findings were similar in both groups of animals (Table I).

\section{Erythrocytes with ${ }^{14} \mathrm{C}$-labeled hemoglobin heme}

Preparation of labeled cells for transfusion. Donor rats were given $50 \mu \mathrm{Ci}$ glycine-2- ${ }^{14} \mathrm{C}^{3}$ intravenously, and were exsanguinated $1,3,5,7,10$, or 15 days later to obtain cohorts of labeled erythrocytes of different ages. Cells were prepared for transfusion as described previously (21). In most

${ }^{2} \mathrm{CD}$ (Sprague-Dawley) rats; Charles River Breeding Labs, Inc., Wilmington, Mass.

${ }^{3}$ Glycine-2- ${ }^{14} \mathrm{C}, 18 \mathrm{mCi} / \mathrm{mmole}$, New England Nuclear Corp., Boston, Mass. experiments blood from three donors was combined for transfusion into two recipient rats. Each transfusion contained $0.1-0.3 \mathrm{~g}$ hemoglobin in a volume of $2-3 \mathrm{ml}$. Disintegrations per minute in transfused hemoglobin heme- ${ }^{14} \mathrm{C}$ were calculated from the hemoglobin content (23) and hemin specific activity (21) of the transfused blood.

Incorporation of glycine $-{ }^{14} \mathrm{C}$ into hemoglobin heme $-{ }^{14} \mathrm{C}$ at the different intervals studied was calculated from the specific activity of hemin and the hemin equivalent of the donor blood volumes. Blood volumes in the controls were estimated on the basis of body weight according to a formula (24) which has been corroborated in this laboratory. Blood volume was measured directly in five iron-deficient rats with ${ }^{51} \mathrm{Cr}$-labeled red cells (24); donor cells were obtained from other anemic animals. Values ranged from 6.6 to $7.3 \%$ of body weight, and the mean of $6.8 \%$ was applied to all other iron-deficient animals.

Bilirubin- ${ }^{14} C$ excretion in recipient rats. Except as noted, recipients were normal rats in which the common bile duct had been cannulated $18 \mathrm{hr}$ before transfusion. Donor cells were injected into a tail vein over $2-3 \mathrm{~min}$, and bile samples were then collected in the dark and on ice at $3.5,24,48$, and $72 \mathrm{hr}$, and in a few experiments also at 96 and $120 \mathrm{hr}$. The excretion of bilirubin $-{ }^{14} \mathrm{C}$ during each collection period was determined from the specific activity of bilirubin and the rate of total bilirubin excretion during that interval (21). Results were expressed as per cent conversion of erythrocyte hemoglobin heme- ${ }^{14} \mathrm{C}$ to bilirubin- $-{ }^{14} \mathrm{C}$ during the first 72 $\mathrm{hr}$, with correction for the loss of one-eighth the glycine $-{ }^{14} \mathrm{C}$ label in heme during degradation to bile pigment (25).

Conditions affecting bilirubin- ${ }^{14} C$ production. The role of the spleen was evaluated in experiments in which donor and/or recipient rats had been subjected to splenectomy. In the donor rats splenectomy or sham-splenectomy was performed 9-11 days before the administration of glycine $-{ }^{14} \mathrm{C}$. Recipients underwent splenectomy at the time of bile duct cannulation.

To determine whether iron deficiency anemia might lead to extracorpuscular changes conducive to reticulocyte hemolysis, bilirubin excretion was measured in two iron-deficient rats given transfusions of labeled reticulocytes from normal donor rats. In an additional experiment, labeled normal reticulocytes were incubated with nonradioactive plasma from iron-deficient rats, 4 volumes of red cells to 7 of plasma, at $37^{\circ} \mathrm{C}$ in air for $45 \mathrm{~min}$ with mild agitation in a metabolic incubator; the cells were then prepared for transfusion into a normal recipient rat with external bile drainage.

\section{Reticulocytes labeled with ${ }^{50} \mathrm{Fe}$}

Labeled reticulocytes were obtained from iron-deficient rats given $15 \mu \mathrm{Ci}$ citrate- ${ }^{60} \mathrm{Fe}{ }^{*} 1$ day earlier (21). Studies with ${ }^{50} \mathrm{Fe}$ were not performed with older cells. Recipients were normal rats that had been prepared with injections of iron-dextran (21) to minimize ${ }^{50} \mathrm{Fe}$ reutilization. Transfusion volumes were small, equivalent to $0.13 \mathrm{~g}$ of hemoglobin, and hematocrits remained stable during the subsequent 3 days of observation. $0.4-\mathrm{ml}$ samples of blood were collected from a tail vein at $15 \mathrm{~min}$, and then at $4,24,48$, and $72 \mathrm{hr}$ for measurement of the specific activity of packed red cells (21). The animal was then sacrificed, and the spleen, liver, and kidneys were removed for radioassay. The per cent of the blood volume normally present in these organs had been measured earlier (21), and the contribution of circulating ${ }^{50} \mathrm{Fe} \mathrm{e}^{-}$

${ }^{4}$ Ferrous citrate- ${ }^{50} \mathrm{Fe}, 16.5 \mathrm{mCi} / \mathrm{mg}$; Abbott Laboratories, North Chicago, Ill. 
labeled red cells to total organ radioactivity was calculated from these values by correcting for the decline in red cell${ }^{50} \mathrm{Fe}$ specific activity during the $72 \mathrm{hr}$ since transfusion; this assumes that intact iron-deficient cells have a distribution similar to that of normal cells. Data for normal reticulocytes are from recent investigations from this laboratory (21).

Incorporation of ${ }^{50} \mathrm{Fe}$ into red cells was measured in two normal and three iron-deficient rats. Citrate ${ }^{60} \mathrm{Fe}^{4}$ was slowly added to fresh heparinized plasma $(5 \mu \mathrm{Ci} / \mathrm{ml})$ from normal or iron-deficient rats, according to the type of animal studied; the mixture was incubated for $30 \mathrm{~min}$ at $37^{\circ} \mathrm{C}$ with occasional agitation. Approximately $2.5 \mu \mathrm{Ci}$ of transferrinbound ${ }^{50} \mathrm{Fe}(0.14 \mu \mathrm{g}$ iron) was injected into a lateral tail vein, and $0.05-\mathrm{ml}$ samples of blood were obtained by tail puncture in heparinized capillary tubes at $1,3,5,7,10$, and 15 days. The tube was centrifuged, the hematocrit measured, and the column of packed red cells counted (21) after discarding the plasma layer. ${ }^{50} \mathrm{Fe}$ incorporation was calculated from counts per minute per milliliter of erythrocytes, hematocrit, and blood volume.

\section{RESULTS}

Hematologic values in 20 groups of iron-deficient donors were as follows: hemoglobin $2.9 \mathrm{~g} / 100 \mathrm{ml}$ (SE 0.1), mean corpuscular hemoglobin concentration $19.1 \%$ ( $\mathrm{SE}$ 0.4 ), and reticulocytes $12.4 \%$ (SE 3.4). Corresponding values for 10 groups of control rats were 13.6 (SE 0.8), 31.8 ( $\mathrm{SE} 1.3$ ), and 1.7 (SE 0.8), respectively.

\section{Erythrocytes with ${ }^{14} \mathrm{C}$-labeled hemoglobin heme}

Incorporation of glycine-2 ${ }^{14} \mathrm{C}$ into hemoglobin heme (Fig. 1). Initially, heme radioactivity in circulating red cells increased at similar rates in both normal and iron-deficient rats. Between 1 and 3 days, however, labeling continued to rise substantially in the normal rats, but increased only slightly in the anemic animals; thus, maximum incorporation of glycine- ${ }^{14} \mathrm{C}$ in the irondeficient animals was approximately half normal. From days 3 to 15 , the level of radioactivity remained more or less constant in the control rats, but fell by a factor of 3-4 in the anemic animals.

Conversion of reticulocyte hemoglobin heme $-{ }^{14} \mathrm{C}$ to bilirubin- ${ }^{14} C$. In rats transfused with labeled reticulocytes from normal donors given glycine- ${ }^{14} \mathrm{C} 1$ day earlier, a mean of $1.7 \%$ of the injected heme ${ }^{14} \mathrm{C}$ was excreted as bilirubin- ${ }^{14} \mathrm{C}$ in 3 days (Table I). In marked contrast, with transfusion of labeled reticulocytes from iron-deficient donors, conversion to bilirubin $-{ }^{14} \mathrm{C}$ averaged $47.3 \%$ in 3 days. The rate of labeled bilirubin excretion was greatest during the first $24 \mathrm{hr}$ after transfusion, and then leveled off gradually over the ensuing 2-4 days.

Alterations in the rate of labeled bilirubin production as a function of the time of labeling of the donor cells are shown in Fig. 2. The mean $72 \mathrm{hr}$ conversion of hemoglobin heme- ${ }^{14} \mathrm{C}$ to bilirubin $-{ }^{14} \mathrm{C}$ fell from $47.3 \%$ with iron-deficient reticulocytes labeled 1 day earlier to

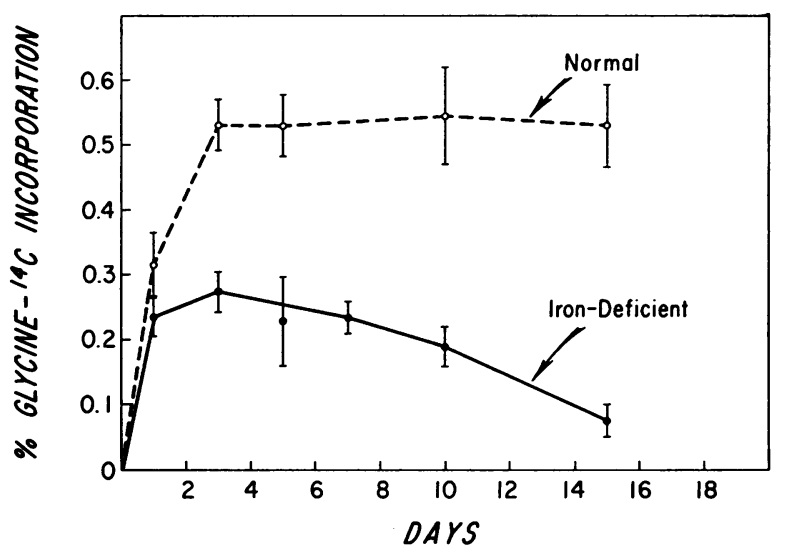

FIgURE 1 Incorporation of glycine-2- ${ }^{14} \mathrm{C}$ into erythrocyte hemoglobin heme as a function of time. Each value is the mean \pm SE (26) of four to six determinations. These were usually performed on pooled donor blood from the transfusion experiments, although several of the control values are based on measurements in four to six single animals. Each rat received $50 \mu \mathrm{Ci}$ glycine $-{ }^{14} \mathrm{C}$.

$35.8 \%$ with cells labeled 3 days previously. With cells from iron-deficient donors given glycine- ${ }^{14} \mathrm{C} 5,7,10$, or 15 days before transfusion, bilirubin production declined further to a plateau averaging $25 \%$.

Conditions affecting bilirubin- ${ }^{14} \mathrm{C}$ production (Table $I)$. The findings with iron-deficient reticulocytes were not influenced by splenectomy of either donor or recipient rats, and the results of all of these experiments have therefore been combined elsewhere in the text. Transfusion of normal reticulocytes into iron-deficient recipients led to a small increase in bilirubin ${ }^{14} \mathrm{C}$ production, suggesting that extracorpuscular factors might contribute to reticulocyte hemolysis in intact iron-deficient animals. It seemed possible that this might be related to plasma constituents, since the plasma of these rats is grossly lipemic as the result of an increase in triglycerides (27); however, preincubation of labeled normal reticulocytes with plasma from iron-deficient animals had little or no effect on the subsequent rate of labeled bilirubin production.

\section{Reticulocytes labeled with ${ }^{50} \mathrm{Fe}$}

Incorporation of ${ }^{59} \mathrm{Fe}$ into erythrocytes. Red cell incorporation of ${ }^{50} \mathrm{Fe}$ in the two normal rats reached maximal values of 92 and $97 \%$ at 5-7 days. By contrast, only $53-61 \%$ incorporation was observed in the three irondeficient rats; these values were reached at 3-5 days. Iron labeling then remained more or less constant through the final measurement at day 15 in both types of animal, in contrast with the decline observed with iron-deficient rats when glycine- ${ }^{14} \mathrm{C}$ was used as the precursor (Fig. 1). 




FIgURE 2 Conversion of transfused hemoglobin heme- $-{ }^{14} \mathrm{C}$ to bilirubin- ${ }^{14} \mathrm{C}$ as a function of the age of the labeled donor cells. Height of each bar represents the mean $( \pm \mathrm{SE}$ ) per cent conversion in $72 \mathrm{hr}$. Transfusions contained $0.82-4.58 \times 10^{5} \mathrm{dpm}$ in red cell hemoglobin heme- ${ }^{14} \mathrm{C}$. Values for 1 day old cells are from experiments with both intact and splenectomized animals (see Table I).

Disappearance of transfused reticulocytes. The disappearance of ${ }^{50} \mathrm{Fe}$-labeled iron-deficient reticulocytes transfused into normal recipients (Fig. 3) was similar to the production of bilirubin $-{ }^{14} \mathrm{C}$ in the corresponding experiments with glycine-labeled cells (Table I). At 72 $\mathrm{hr}$, specific activities had fallen an average of $38 \%$ below the initial values measured at $15 \mathrm{~min}$ as compared with only $3.5 \%$ with cells from normal donors.



FIGURE 3 Disappearance of ${ }^{50} \mathrm{Fe}$-labeled reticulocytes in normal recipient rats. Initial specific activities measured at $15 \mathrm{~min}$ ranged from 3.47 to $4.08 \times 10^{4} \mathrm{cpm} / \mathrm{ml}$ in the experiments with iron-deficient reticulocytes, and from 4.78 to $11.85 \times 10^{4} \mathrm{cpm} / \mathrm{ml}$ in those with normal reticulocytes. Means \pm SD are plotted for normal cells.
Both the spleens and livers of animals given transfusions of ${ }^{50} \mathrm{Fe}$-labeled iron-deficient reticulocytes contained substantially larger amounts of radioactivity than did those of animals given normal reticulocytes (Table II). These differences are more striking after total organ radioactivity is corrected for the content of ${ }^{50} \mathrm{Fe}$ in organ blood (values in parentheses), since the latter accounted for most of the radioactivity in the control experiments. Expressed in either manner, the radioactive content of the spleen exceeded that of the liver in recipients of iron-deficient cells. Only low levels of radioactivity were found in the kidneys in both groups of animals.

TABLE II

Recovery of Transfused Reticulocyte- ${ }^{59} \mathrm{Fe}$ in Organs of Recipients

\begin{tabular}{lcccc}
\hline & & \multicolumn{3}{c}{ \% Recovery of ${ }^{\circ 0 \mathrm{Fe}^{*}}$} \\
\cline { 4 - 5 } Cell type & $\begin{array}{c}\text { Num- } \\
\text { ber }\end{array}$ & Spleen & Liver & Kidneys \\
\hline $\begin{array}{c}\text { Normal } \\
\text { reticulocytes }\end{array}$ & 8 & $\begin{array}{c}1.7 \pm 0.1 \\
(0.7)\end{array}$ & $\begin{array}{c}5.4 \pm 0.8 \\
(0.4)\end{array}$ & $\begin{array}{c}0.7 \pm 0.1 \\
(0)\end{array}$ \\
$\begin{array}{c}\text { Iron-deficient } \\
\text { reticulocytes }\end{array}$ & 3 & $\begin{array}{c}16.5 \pm 0.4 \\
(15.8)\end{array}$ & $\begin{array}{c}12.2 \pm 1.7 \\
(9.0)\end{array}$ & $\begin{array}{c}0.6 \pm 0.2 \\
(0.3)\end{array}$ \\
\hline
\end{tabular}

Values are means $\pm \mathrm{SE}(26)$. Numbers in parentheses refer to ${ }^{59} \mathrm{Fe}$ recovery after correction for organ blood- ${ }^{59} \mathrm{Fe}$.

* Rats received $3.17 \times 10^{5} \mathrm{cpm}$ in ${ }^{59} \mathrm{Fe}$-labeled cells in the experiments with iron-deficient reticulocytes, and $6.42-$ $7.33 \times 10^{5} \mathrm{cpm}$ in those with normal cells. 


\section{DISCUSSION}

These experiments provide direct confirmation both of the concept of ineffective erythropoiesis and of the relationship of this pathophysiologic process to the erythropoietic fraction of bile pigment formation. Together with previous studies, they indicate that degradation of hemoglobin from immature erythroid cells accounts in large measure for the increased production of early-labeled bilirubin both in rats with abnormal erythropoiesis due to severe iron deficiency (22) and in animals with physiologically regulated erythroid hyperplasia (21). This confirms the suggestion of earlier investigators that reticulocyte hemolysis might be a source of early bilirubin formation $(3,12,28)$.

Not surprisingly, there was also increased destruction of mature red cells in the iron-deficient rats; the mean value for bilirubin $-{ }^{14} \mathrm{C}$ production with transfusion of 10 day old iron-deficient cells was $27.9 \%$ in 3 days (Fig. 2 ), as compared with only $2.5 \%$ for normal cells of this age (21). Since both the amount of hemoglobin heme $-{ }^{14} \mathrm{C}$ present in the donor blood and its rate of conversion to bilirubin $-{ }^{14} \mathrm{C}$ diminished with increasing red cell age (Figs. 1 and 2 ), the absolute magnitude of labeled pigment formation was greatest with transfusion of 1 day old iron-deficient cells, declined moderately with 3 day old cells, and then fell off more steeply, as would be expected from the pattern of early-labeled bilirubin production in intact iron-deficient rats (22).

On the basis of the data in Figs. 1 and 2, hemolysis of labeled reticulocytes could account for $0.11 \%$ glycine${ }^{14} \mathrm{C}$ incorporation into bilirubin- ${ }^{14} \mathrm{C}$ in 3 days. In studies of early-labeled pigment formation from all potential sources, intact iron-deficient rats incorporated $0.13 \%$ of the injected glycine $-{ }^{14} \mathrm{C}$ into labeled bilirubin during the first $60 \mathrm{hr}(22)$; some of this is nonerythroid in origin $(5-11,22)$. Comparison of labeled bilirubin production in rats given transfusions of labeled cells and intact animals given glycine $-{ }^{14} \mathrm{C}$ directly serves only as an approximation. Nevertheless, it is apparent that degradation of reticulocyte hemoglobin is of sufficient magnitude to account for a major portion of the enlarged erythropoietic bilirubin component in experimental iron deficiency. Since the earliest transfusions were performed 1 day after the administration of glycine $-{ }^{14} \mathrm{C}$ to the donor rats, it is possible that other mechanisms, perhaps including hemolysis of less mature cells in the bone marrow, played a significant role during the first $24 \mathrm{hr}$.

Study of labeled bilirubin production permits precise evaluation of the rate of degradation of erythrocyte hemoglobin and circumvents a number of problems inherent in other techniques. Measurement of red cell incorporation of ${ }^{50} \mathrm{Fe}$ failed to show hemolysis, presumably because of avid ${ }^{50} \mathrm{Fe}$ reutilization in the iron- deficient animals. McKee, Wasson, and Heyssel did demonstrate reticulocyte hemolysis in iron-deficient rats with ${ }^{50} \mathrm{Fe}$, by iron loading the animals after the isotope was given (29) ; however, they found only mild hemolysis of older cells. Reutilization of glycine $-{ }^{12} \mathrm{C}$ also occurs to a small extent (30); this probably explains why direct labeling of hemoglobin heme with glycine $-{ }^{14} \mathrm{C}$ did not demonstrate preferential hemolysis of the youngest cells and fell off at a rate of only $5-6 \%$ per day (Fig. 1), whereas the bilirubin studies reflected a decreasing rate of hemolysis over a range of $16-7 \%$ per day (Fig. 2). On the other hand, the findings with transfusion of ${ }^{50} \mathrm{Fe}$-labeled reticulocytes (Fig. 3) did correspond to those based on bilirubin ${ }^{14} \mathrm{C}$ production; however, in studies of reticulocytes produced in response to hemorrhage, these two techniques led to somewhat different results that were attributed tentatively to loss of nonheme iron or to some cell sequestration without hemolysis (21). Moreover, measurement of red cell specific activity, unlike measurement of tabeled bilirubin production, requires maintenance of the erythropoietic steady state.

Potential liabilities of the bilirubin technique have been considered elsewhere (21), but issues pertinent to the present investigation merit brief comment. It is possible that reutilization of glycine- ${ }^{14} \mathrm{C}$ in the donor rats may have "contaminated" the cohorts of older labeled cells with labeled reticulocytes, thus exaggerating the apparent hemolytic susceptibility of these older cells. It is also conceivable that the large amounts of labeled bilirubin produced by the recipients of iron-deficient erythrocytes originated not from hemoglobin heme, but from the excess free protoporphyrin present in such cells $(31,32)$; however, the almost parallel findings with ${ }^{50} \mathrm{Fe}$ - and glycine-labeled reticulocytes implicate the equivalent loss of both the iron and porphyrin moieties of entire heme molecules. Finally, it is perhaps surprising that splenectomy did not influence the rate of bilirubin ${ }^{14} \mathrm{C}$ production (Table $\mathrm{I}$ ), in view of the high levels of splenic radioactivity observed in the experiments with ${ }^{80} \mathrm{Fe}$-labeled cells (Table II). The liver may have compensated for the absence of the spleen (21). Alternatively, it is possible that the spleen had offsetting effects, both protective (33) and destructive, on these immature cells.

Iron deficiency anemia differs in certain respects in experimental animals and in man. Reticulocytosis is not typical of iron-deficient patients, although a moderate increase in the reticulocyte count is probably not uncommon $(29,34,35)$; reticulocytosis is characteristically found in animals with iron deficiency anemia $(29,36$, $37)$. Studies differ with regard to the presence of hemolysis in iron-deficient humans (38-42); hemolysis is readily confirmed in the experimental disorder $(29$, 
37, 43) (Figs. 1 and 2). Finally, ${ }^{50} \mathrm{Fe}$ incorporation into red cells is rapid and high in patients with iron deficiency $(44,45)$, but was below normal in this investigation of iron-deficient rats. The present findings may therefore not be entirely applicable to man. However, analyses of ${ }^{50} \mathrm{Fe}$ turnover in human subjects are consistent with ineffective erythropoiesis $(44,45)$, as are studies of chelatable iron before and after iron therapy (46). It is therefore likely that the differences between the findings in rats and man are largely a matter of degree, with a more marked impairment in survival of both young and old cells in the experimental disorder.

If the increase in erythropoietic bilirubin production in experimental iron deficiency anemia is of similar origin to that in the physiologic response to blood loss (21), what accounts for the decrease in net hemoglobin production in the former and the increase in the latter condition? Since the rate of hemoglobin degradation is as high as $16 \%$ per day with iron-deficient reticulocytes (Table I), as compared with only $2.2 \%$ per day with "stress reticulocytes" from rats after blood loss (21), this appears to be largely a quantitative phenomenon. However, recent observations are causing us to reevaluate this attractive and unifying concept. Stress reticulocytes appear to undergo heme loss primarily by a process of fragmentation, with loss of only portions of hemoglobinized cytoplasm $(47-49)$. On the other hand, the magnitude of bilirubin ${ }^{14} \mathrm{C}$ production with iron-deficient reticulocytes suggests that hemolysis of whole cells must be involved to a large extent. Although this is a subject for further investigation, it is tempting to speculate that fragmentation and hemolysis are parts of a spectrum that underlies much of the increase in erythropoietic bilirubin formation under both physiologic and pathologic conditions.

\section{ACKNOWLEDGMENTS}

This work was supported in part by Grant AM 09834 and Career Development Award AM 19600 (Dr. Robinson) from the U. S. Public Health Service.

\section{REFERENCES}

1. Robinson, S. H. 1969. Bilirubin production from erythropoietic and nonerythroid sources in experimental iron deficiency anemia. J. Clin. Invest. 48: 69a. (Abstr.)

2. Robinson, S. H., and E. Koeppel. 1970. Preferential hemolysis of immature erythroid cells in experimental iron deficiency anemia. Blood. 36: 848 .

3. London, I. M., R. West, D. Shemin, and D. Rittenberg. 1950. On the origin of bile pigment in normal man. $J$. Biol. Chem. 184: 351.

4. Gray, C. H., A. Neuberger, and P. H. A. Sneath. 1950. Studies in congenital porphyria. II. Incorporation of ${ }^{15} \mathrm{~N}$ in the stercobilin in the normal and in the porphyric. Biochem. J. 47: 87.

5. Robinson, S. H., M. Tsong, B. W. Brown, and R. Schmid. 1966. The sources of bile pigment in the rat: studies of the "early-labeled" fraction. J. Clin. Invest. 45: 1569.

6. Robinson, S. H., C. A. Owen, Jr., E. V. Flock, and R. Schmid. 1965. Bilirubin formation in the liver from nonhemoglobin sources. Experiments with isolated, perfused rat liver. Blood. 26: 823 .

7. Schwartz, S., G. Ibrahim, and C. J. Watson. 1964. The contribution of nonhemoglobin hemes to the early labeling of bile bilirubin. J. Lab. Clin. Med. 64: 1003. (Abstr.)

8. Levitt, M., B. A. Schacter, A. Zipursky, and L. G. Israels. 1968. The nonerythropoietic component of early bilirubin. J. Clin. Invest. 47: 1281.

9. Robinson, S. H. 1969. Increased bilirubin formation from nonhemoglobin sources in rats with disorders of the liver. J. Lab. Clin. Med. 73: 668.

10. Israels, L. G., T. Yamamoto, J. Skanderbeg, and A. Zipursky. 1963. Shunt bilirubin: evidence for two components. Science (Washington). 139: 1054.

11. Ibrahim, G. W., S. Schwartz, and C. J. Watson. 1966. Early labeling of bilirubin from glycine and deltaaminolevulinic acid in bile fistual dogs with special reference to stimulated versus suppressed erythropoiesis. $M e$ tab. Clin. Exp. 15: 1129.

12. Gray, C. H., and J. J. Scott. 1959. The effect of hemorrhage on the incorporation of $\left[\alpha-{ }^{14} \mathrm{C}\right]$ glycine into stercobilin. Biochem. J. 71: 38.

13. Israels, L. G., J. Skanderbeg, H. Guyda, W. Zingg, and A. Zipursky. 1963. A study of the early-labelled fraction of bile pigment: the effect of altering erythropoiesis on the incorporation of $\left[2{ }^{14} \mathrm{C}\right]$ glycine into haem and bilirubin. Brit. J. Haematol. 9: 50.

14. London, I. M., and R. West. 1950. The formation of bile pigment in pernicious anemia. J. Biol. Chem. 184: 359.

15. Grinstein, M., R. M. Bannerman, J. D. Vavra, and C. V. Moore. 1960. Hemoglobin metabolism in thalassemia: in vivo studies. Amer. J. Med. 29: 18.

16. Robinson, S. H., T. Vanier, J. F. Desforges, and R. Schmid. 1962. Jaundice in thalassemia minor. A consequence of "ineffective erythropoiesis." N. Engl. J. Med. $267: 523$.

17. Barrett, P. V. D., M. J. Cline, and N. I. Berlin. 1966. The association of the urobilin "early peak" and erythropoiesis in man. J. Clin. Invest. 45: 657.

18. Giblett, E. R., D. H. Coleman, G. Pirzio-Biroli, D. M. Donahue, A. G. Motulsky, and C. A. Finch. 1956. Erythrokinetics: quantitative measurements of red cell production and destruction in normal subjects and patients with anemia. Blood. 11: 291.

19. Robinson, S. H. 1968. The origins of bilirubin. N. Engl. J. Med. 279: 143.

20. London, I. M., G. P. Bruns, and D. Karibian. 1964. The regulation of hemoglobin synthesis and the pathogenesis of some hypochromic anemias. Medicine (Baltimore). 43: 789 .

21. Robinson, S. H., and M. Tsong. 1970. Hemolysis of "stress" reticulocytes: a source of erythropoietic bilirubin formation. J. Clin. Invest. 49: 1025.

22. Robinson, S. H. 1969. Increased formation of earlylabeled bilirubin in rats with iron deficiency anemia: evidence for ineffective erythropoiesis. Blood. 33: 909.

23. Cartwright, G. E. 1968. Diagnostic Laboratory Hematology. Grune \& Stratton, Inc., New York. 4th edition.

24. Keene, W. R., and J. H. Jandl. 1965. Studies of the reticuloendothelial mass and sequestering function of rat bone marrow. Blood. 26: 157. 
25. Ostrow, J. D., L. Hammaker, and R. Schmid. 1961. The preparation of crystalline bilirubin- $\mathrm{C}^{14}$. J. Clin. Invest. 40: 1442.

26. Snedecor, G. W., and W. G. Cochran. 1967. Statistical Methods. Iowa State University Press, Ames, Iowa. 6th edition.

27. Lewis, M. 1969. Selective increase in triglyceride in iron deficiency anemia. Blood. 34: 853 .

28. Berendes, M. 1959. The proportion of reticulocytes in the erythrocytes of the spleen as compared with those of circulating blood, with special reference to hemolytic states. Blood. 14: 558.

29. McKee, L. C., Jr., M. Wasson, and R. M. Heyssel. 1968. Experimental iron deficiency in the rat. The use of ${ }^{51} \mathrm{Cr}, \mathrm{DF}^{22} \mathrm{P}$ and ${ }^{50} \mathrm{Fe}$ to detect haemolysis of iron-deficient cells. Brit. J. Haematol. 14: 87.

30. Berlin, N. I., C. Hewitt, and C. Lotz. 1954. Hippuric acid synthesis in man after the administration of $\left[\alpha-{ }^{14} \mathrm{C}\right]$ glycine. Biochem. J. 58: 498.

31. Watson, C. J. 1950. The erythrocyte coproporphyrin. Variation in respect to erythrocyte protoporphyrin and reticulocytes in certain of the anemias. Arch. Intern. Med. 86: 797.

32. Ibrahim, G. W., S. Schwartz, and C. J. Watson. 1966. The conversion of protoporphyrin- $\mathrm{C}^{14}$ to heme compounds and bilirubin in dogs. Metab. Clin. Exp. 15: 1120.

33. Jandl, J. H. 1960. The agglutination and sequestration of immature red cells. J. Lab. Clin. Med. 55: 663

34. Wintrobe, M. M., and R. T. Beebe. 1933. Idiopathic hypochromic anemia. Medicine (Baltimore). 12: 187.

35. Heath, C. W., and A. J. Patek, Jr. 1937. The anemia of iron deficiency. Medicine (Baltimore). 16: 267.

36. Mendel, G. A., R. J. Weiler, and A. Mangalik. 1963. Studies on iron absorption. II. The absorption of iron in experimental anemias of diverse etiology. Blood. 22: 450.

37. Huser, H. J., E. E. Rieber, and A. R. Berman. 1967. Experimental evidence of excess hemolysis in the course of chronic iron deficiency anemia. J. Lab. Clin. Med. 69: 405.
38. Layrisse, M., J. Linares, and M. Roche. 1965. Excess hemolysis in subjects with severe iron deficiency anemia associated and nonassociated with hookworm infection. Blood. 25: 73.

39. Loría, A., L. Sánchez-Medal, R. Lisker, E. de Rodríguez, and J. Labardini. 1967. Red cell life span in iron deficiency anaemia. Brit. J. Haematol. 13: 294.

40. Verloop, M. C., M. van der Wolk, and A. J. Heier. 1960. Radioactive iron studies in patients with iron deficiency anemia with concurrent abnormal hemolysis. Blood. 15: 791.

41. Temperley, I. J., and A. A. Sharp. 1962. The life span of erythrocytes in iron-deficiency anaemia. J. Clin. $\mathrm{Pa}$ thol. (London). 15 : 346.

42. Gilles, H. M., E. J. Watson Williams, and P. A. J. Ball. 1964. Hookworm infection and anaemia. An epidemiological, clinical and laboratory study. Quart. J. Med. 33: 1.

43. Card, R. T., and L. R. Weintraub. 1969. Metabolic abnormalities of erythrocytes in severe iron deficiency. Blood. 34 : 853.

44. Pollycove, M. 1966. Iron metabolism and kinetics. Seminars Hematol. 3: 235.

45. Finch, C. A., K. Deubelbeiss, J. D. Cook, J. W. Eschbach, L. A. Harker, D. D. Funk, G. Marsaglia, R. S. Hillman, S. Slichter, J. W. Adamson, A. Ganzoni, and E. R. Giblett. 1970. Ferrokinetics in man. Medicine (Baltimore). 49: 17.

46. Brunström, G. M., C. Karabus, and J. Fielding. 1968. The effect of small doses of iron on desferrioxamine chelation in iron-deficiency anaemia: evidence for ineffective erythropoiesis. Brit. J. Haematol. 14: 525.

47. Ganzoni, A., R. S. Hillman, and C. A. Finch. 1969. Maturation of the macroreticulocyte. Brit. J. Haematol. 16: 119 .

48. Come, S. E., S. B. Shohet, and S. H. Robinson. 1971. Fate of stress reticulocytes: hemolysis or fragmentation? J. Clin. Invest. 50: 21a. (Abstr.)

49. Shattil, S. J., and R. A. Cooper. 1971. Maturation of the reticulocyte membrane in vivo. Clin. Res. 19: 431. (Abstr). 